\title{
Generating genetic diversity through diallel crosses of promising potato cultivars (Solanum tuberosum L.) and studying cultivar hybrids under water deficit stress
}

\author{
Mohammad Reza Vesali ${ }^{1}$, Reza Baradaran ${ }^{1 *}$, Davoud Hassanpanah ${ }^{2}$, Mohammad Javad \\ Seghatoleslami ${ }^{1}$ \\ ${ }^{1}$ Department of Agronomy and Plant Breeding, Islamic Azad University, Birjand Branch, Iran. E-mail: \\ sd93.vesali_mohamadreza@iaubir.ac.ir,baradaran@iaubir.ac.ir, mjseghat@iaubir.ac.ir \\ ${ }^{2}$ Horticulture Crops Research Department, Ardabil Agricultural and Natural Resources Research and Education Center, AREEO, \\ Ardabil, Iran. E-mail: d.hassanpanah@areeo.ac.ir \\ * corresponding author \\ Received: 16/03/2020; Accepted: 29/04/2020.
}

\begin{abstract}
This research was conducted from 2017 to 2018 to produce genetic diversity and examine selected suitable hybrids concerning certain agricultural traits under normal and water-deficit stress conditions in a Zarghostar-Arta company. In 2017, four potato cultivars, namely, Luca, Banba, Esprit, and Agria, were crossed as parents via mutual hybridization based on the diallel method guided by Griffing's method III. About 8550 true potato seeds were produced, among which 3944 seeds were germinated, and 151 hybrids were selected for culturing on a split-plot with a randomized complete block design involving three replications. The main factors of interest in the design were three irrigation levels (100\%, $85 \%$, and $70 \%$ water supply requirements), and the sub-factors were 12 populations. The highest specific combining ability for tuber yield was found in the direct cross of the ${ }^{\wedge}$ LucaxEsprit + compound under normal and mild conditions. In mild and severe stress conditions, the hybrid of $q$ Luca $\times$ Agria $\bigcirc$ and the direct cross of the $q$ LucaxEsprit $q$ compound had the highest tuber yields. The general heritability of tuber yield ranged from $81.68 \%$ (in $70 \%$ available water) to $94.66 \%$ (in $100 \%$ available water), and the specific heritability ranged from $62.39 \%$ (in $85 \%$ available water) to $86.78 \%$ (in 100\% available water). Additive variances in the varieties were 118.05, 46.92, and 37.49, and dominance variances were $33.82,8.97$, and 0.68 in $100 \%, 85 \%$, and $70 \%$ available water, respectively.
\end{abstract}

Keywords: tuber yield, general combining ability (GCA), specific combining ability (SCA).

\section{Gerando diversidade genética por meio de cruzamentos dialelos de cultivares promissoras de batata (Solanum tuberosum L.) e do estudo de cultivares híbridos sob estresse hídrico}

\section{RESUMO}

Esta pesquisa foi realizada de 2017 a 2018, com o objetivo de produzir diversidade genética e examinar híbridos adequados selecionados em relação a certas características agrícolas em condições normais e de estresse hídrico, em uma empresa da Zarghostar-Arta. Em 2017, quatro cultivares de batata, Luca, Banba, Esprit e Agria, foram cruzadas como progenitores por hibridação mútua, com base no método dialelo guiado pelo método III de Griffing. Foram produzidas cerca de 8550 sementes verdadeiras de batata, dentre as quais 3944 foram germinadas e 151 híbridos foram selecionados para cultura, em parcelas subdivididas num delineamento em blocos casualizados, com três repetições. Os principais fatores de interesse no projeto foram três níveis de irrigação (requisitos de suprimento de água de 100\%, 85\% e 70\%), e os subfatores foram 12 populações. A maior capacidade específica de combinação para o rendimento de tubérculos foi encontrada no cruzamento direto do composto ${ }^{\lambda}$ Luca $\times$ Esprit $\bigcirc$, sob condições normais e amenas. Em condições de

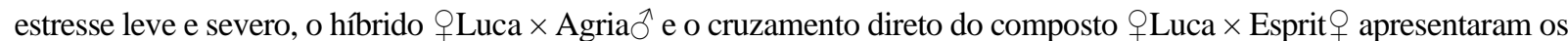
maiores rendimentos de tubérculos. A herdabilidade geral do rendimento de tubérculos variou de $81,68 \%$ (em $70 \%$ de água disponível) a 94,66\% (em 100\% de água disponível), e a herdabilidade específica variou de 62,39\% (em 85\% de água disponível) a 86,78\% (em 100\% água disponível). As variações aditivas nas variedades foram 118,05, 46,92 e 37,49, e as variações de dominância foram 33,82, 8,97 e 0,68, em 100\%, 85\% e 70\% de água disponível, respectivamente.

Palavras-chave: rendimento de tubérculos, capacidade geral de combinação (CGC), capacidade específica de combinação (CEC). 


\section{Introduction}

The potato (Solanum tuberosum L.) is the third most important food crop worldwide. It has a high concentration of carbohydrates as a source of energy, significant amounts of quality protein, and substantial amounts of vitamins, especially vitamin C. Potato proteins are particularly rich in aspartic acid and glutamic acids; they also contain considerable levels of leucine, valine, alanine, lysine, and arginine (Çelik et al., 2015). Potato cultivars around the world are mostly constituted by tetraploid and clonally propagated varieties (Jansky and Spooner, 2018).

For over a century, the breeding strategy for potato has been recurrent phenotypic selection. The polyploid nature of the crop, however, prevents breeders from eliminating deleterious alleles and assembling positive ones for the large array of traits necessary in a successful cultivar.

Potato breeders have assumed that cultivars must be tetraploid (Jansk and Spooner, 2018) in nature. To look into this matter, Collins (1977) used eight clones as parents in a modified diallel-crossing design that generated 24 families, each consisting of 10 full-sib clones. The diallel analysis of the 24 families revealed significant effects related to general and specific combining abilities.

Tai (1976) studied seven quantitative traits in potato cultivars in a partial diallel cross experiment. The author observed considerable specific combining ability (SCA) effects on total and marketable tuber yields, the total number of tubers, and the number of marketable tubers. $\mathrm{He}$ also found sizable general combining ability (GCA) effects on total and marketable weights per tuber and specific gravity. The SCA effects on specific gravity were significant, and the heritability estimated based on the GCA effects indicated that the parents could be efficiently selected for average tuber weight and specific gravity.

Neele et al. (1991) used an incomplete diallel cross to examine the components of genetic variations in potato for a range of characters after early and late harvests. For almost all the traits, the GCA effects were predominant, although the SCA effects that arose were greater in the late harvest than in the early one. The seedling performance for tuber yield, the number of tubers, and the average tuber weight showed no relevant relationship with field performance.

In general, the mid-parent value enabled satisfactory predictions of the mean progeny performance obtained in the diallel, except for ware tuber yield. The selfed and diploid progenies did not improve the prediction of progeny means compared with the prediction of the midparent value. The predictions based on test crosses surpassed those grounded in the mid-parent value, particularly for tuber yield at the ware potato harvest. The authors also discussed methods for identifying superior parents.

Bradshaw et al. (2000) analyzed combining ability. They identified fry color, emergence, maturity, yield, dry matter, and sprouting resistance as traits for which variances in GCA and narrow-sense heritability were high enough for good progress from a full-sib family selection. Correlations between the GCAs of pairs of traits were examined, including those from previously published seedling progeny tests. Clones with high GCAs were identified for use as parents in future breeding, and the extent to which GCAs can be predicted based on parents was ascertained.

The offspring means from the mid-parent means was determined via regression and correlation analyses. The offspring-mid-parent regression was highest for fry color, followed by dry matter, emergence, and sprouting. Values were lower for scab because of environmental variations. About maturity, yield, and tuber size depended on SCA, and visual preference was affected by both factors. The authors discussed implications for a breeding strategy.

Mwanga et al. (2002) crossed ten parental clones in a half diallel mating design to generate 45 full-sib families. They conducted a genetic component analysis, which uncovered significant effects on general and specific combining abilities. Two genotypes, New Kawogo and Sowola, exhibited highly adverse GCA effects and produced several families in specific crosses.

Aliu et al. (2008) evaluated GCA and SCA in 10 inbred lines and their F1 hybrids based on a diallel cross (without reciprocals). The results from additive gene effects were more important than those from additives.

El-Badawy (2013) assessed GCA and SCA in seven inbred lines of maize and found that the squares of GCA and SCA means were significant for all traits. The GCA/SCA ratios determined through a combined analysis revealed that additives and additive types of gene action were the most important expressions for days to $50 \%$ maturity, the numbers of rows per ear, and shelling percentage.

These crosses might be of prime importance in breeding programs geared toward either hybrid maize production or synthetic varieties composed of hybrids that are generated using good combiners of traits in view evaluated 44 potato genotypes in three environments in Rwanda to select high-yielding and late blight-resistant parents.

The genotypes significantly differed in terms of blight resistance and yield levels across test locations. Eighteen genotypes (CIP 393371.58, CIP 393637.171, CIP 396033.102, CIP 395112.36, CIP 393280.57, CIP 393385.39, CIP 396026.103, CIP 393280.82, CIP 396036.201, CIP 393077.54, CIP 391047.34, CIP 39111.19, CIP 381381.13, Ngunda, Kigega, Kirundo, 
Nderera, and Gikungu) were identified as resistant to late blight, producing high tuber yield, and having a dry matter percentage.

Harriman and Nwammadu (2016) In plant breeding, various mating designs and arrangements are used by breeders and geneticists to generate improved plants. The selection of good mating designs is key to successful plant breeding schemes. Diallel mating designs that come into play when the same parents are used as females and males in breeding are an important tool in plant breeding programs to obtain information on inheritance, such as GCA, SCA, and heritability of qualitatively or complexly inherited traits. The understanding of this mating design and in-depth knowledge in the interpretation of inheritance estimates is a basic prerequisite for crop improvement. Therefore, this review aimed at highlighting the meaning of diallel mating design in plant breeding and some statistical interpretation of its components for successful

Panel (2017) reported that a potato breeding program in Ireland country included selection for crisping, chipping, salad, and ware varieties and increasing exports. It also encompasses using Irish-grown potatoes for processing and salad markets as well as expanding the seed export market. The author indicated that over $70 \%$ of the total number of potatoes grown in Ireland is Teagasc varieties.

Baafi et al. (2017) used a diallel mating design to elucidate general, and specific combining abilities and determine whether gene action controls dry matter from storage root and starch and sugar concentrations in sweet potato. The authors also established the heterotic potential of traits to facilitate crop improvement for increased utilization. Genetic variability was observed in the dry matter and starch and sugar concentrations, and the findings revealed that the majority of genetic variation was additive. Kaushik and Dhaliwal (2018) used Griffing's method II to determine the inheritance of traits in tomato. The authors found significant general and specific combining abilities.

Gautam et al. (2018) concluded that the significant mean squares of GCA and SCA indicated a joint role of additive and non-additive gene effects in the expression of quality traits. Swetha et al. (2018) estimated the GCA of parents and the SCA of hybrids to identify highyielding and better-quality cultivars. Eight genotypes and 28 F1 hybrids were derived by crossing eight parental cotton genotypes in a half diallel mating system. The results from parent TCB 37 and GSB 21 were good combiners for generating fiber quality traits.

Sharavati et al. (2018) approximated genetic variability, heritability, and genetic advance for growth and yield parameters in 30 genotypes. Traits such as leaf area, tuber weight, total tuber yield, and marketable yield per hectare had more than $20 \%$ of the phenotypic variation coefficient (PVC) and genotypic coefficient of variation (GVC).

Ngailo et al. (2019) determined the combining ability and heterosis of selected sweet potato clones to identify the number of storage roots per plant, storage root yield, dry matter content, and resistance to sweet potato virus disease. These variables were considered concerning breeding. Eight selected genotypes were crossed using an $8 \times 8$ half diallel mating design to generate 28 families, which were then evaluated along with their parents under field conditions. General and specific combining ability effects were highly significant among the families.

With consideration for the developments mentioned above, the current research was performed to create genetic diversity and access suitable hybrids for the generation of quantitative traits and the advancement of cultivar adaptation to the climatic conditions of Iran. Hybrid cultivars were examined in the laboratory and greenhouse of Zarghostar-Arta Company from 2017 to 2018.

\section{Material and Methods}

In 2017, four cultivars (Luta, Banba, Esprit, and Agria) were used as parents in an experimental design characterized by mutual hybridization based on a diallel analysis guided by Griffing's method III (F1 through cross-linking) (Griffing, 1956). True potato seeds (TPSs) produced from similar crosses were harvested together. The first breeding gene included commercial cultivars from the Tuberosum group, and breeding was undertaken in a greenhouse of the Zarghostar-Arta Company of Ardabil Province, Iran. The province is located at an elevation of $1349 \mathrm{~m}$ at $20^{\circ}, 48^{\prime}$ latitude and $38^{\circ}, 15^{\prime}$ longitude. It has temperatures of $1.98^{\circ} \mathrm{C}$ to $21.58^{\circ} \mathrm{C}$ and experiences an average of about $310 \mathrm{~mm}$ of rainfall annually.

During the breeding cycle, in the growing season, and after harvest, the research recorded data on the percentage of seed germination, transplant survival, berry number, and seed production. The TPSs of each offspring produced were soaked in a solution of 1500 ppm gibberellic acid for $24 \mathrm{~h}$. After this, all the seeds were planted in plastic trays (Ortiz and Golmirzaie, 2003) containing peat moss and mineral pumice at a volume ratio of 1:1 (Hassanpanah et al., 2018) in June 2017.

When the seedlings reached a height of approximately 3 to $5 \mathrm{~cm}$, they were transferred into plastic pots containing a mixture of peat moss and mineral pumice at a ratio of $1: 1(\mathrm{v} / \mathrm{v})$. They were grown to 15 to $20 \mathrm{~cm}$ high (Ortiz and Golmirzaie, 2003). During the growth stages, irrigation and weeding were carried out regularly. Superphosphate fertilizer $\left(150 \mathrm{~kg} \cdot \mathrm{ha}^{-1}\right)$ was applied two times (50\% during planting time and 50\% at the period of tuber formation). Urea fertilizer (300 kg.ha- 
$\left.{ }^{1}\right)$ was used three times (25\% at planting time, $50 \%$ at the time of emergence, and $25 \%$ immediately after tuber formation). Potassium sulfate fertilizer $\left(100 \mathrm{~kg} \cdot \mathrm{ha}^{-1}\right.$ at planting time) was used based on a soil test. Pest control was implemented using Confidor poison ( 0.25 per thousand). For the control of fungal diseases, Mancozeb fungus (1 kg.ha ${ }^{-1}$ in $400 \mathrm{~L}$ of water) was employed. Subsequently, 12 breeding populations were transferred after six weeks to single-row plots in the field (Ortiz and Golmirzaie, 2003) in July 2017.

Hybrids were also transferred and planted in the field. The field plots were single rows of $75 \mathrm{~cm}$, with plants spaced $30 \mathrm{~cm}$ apart (Hassanpanah et al., 2018). After the hybrids were harvested, they were evaluated in terms of eye depth $(1=$ deep eyes to $9=$ shallow eyes $)$, tuber skin color $(1=$ yellow to $4=$ purple), general plant appearance ( $1=$ poor to $9=$ excellent $)$, stolon length $(1=$ long to $9=$ short), general impression $(1=$ very high to $5=$ very poor), uniformity in tuber size, regularity in tuber shape ( $1=$ irregular to $9=$ regular $)$, tuber shape $(1=$ round to 5 $=$ long), and tuber number and weight per plant (Neele et al., 1991).

The hybrids selected from the breeding populations were planted on a split-plot based on randomized complete block design, with three replications implemented in May 2018. The main factors of interest in the design were three levels of irrigation $(100 \%, 85 \%$, and $70 \%$ water requirement for plants), and the subfactors were 12 breeding populations ( Luca $_{\text {Banba }}{ }^{\top}$,

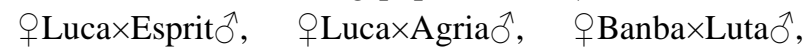

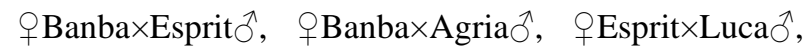

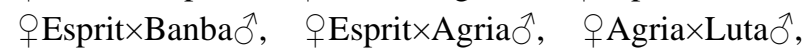

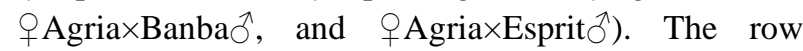
spacing for planting was $75 \mathrm{~cm}$, and the distance between the plants was $30 \mathrm{~cm}$ (Hassanpanah et al., 2018). The amount of irrigation water was determined at each stage of potato growth. Each level of irrigation was grounded in FC (field capacity), PWP (permanent wilting point), Bd.D (bulk density), AW (available water), RAW(readily available water), and MAD (maximum allowable depletion), (Rasoulzadeh and Raof, 2013). The calculations reflected that soil moisture content was $21.56 \%$ at the initiation of irrigation under normal conditions. Soil moisture concentration during the growing stages was determined using a portable soil moisture meter (PMS-714, Taiwan). As previously stated, the irrigation requirements considered were $100 \%, 85 \%$, and $70 \%$. The water supplied to potato plants through tape irrigation is shown in Table 1.

During the growing season and after harvest, data on tuber smoothness were recorded to determine early season growth $(1=$ slow growth to $9=$ rapid growth $)$, tuber skin color $(1=$ yellow to $4=$ purple $)$, tuber flesh color, tuber shape $(1=$ round to $5=$ long $)$, uniformity in tuber size, regularity in tuber shape $(1=$ irregular to $9=$ regular), maturity, number of tubers per plant, tuber weight per plant, tuber yield, number of main stems per plant, main stem diameter, plant height, percentage of tuber dry matter, and efficiency of water use (Neele et al., 1991; Ortiz and Golmirzaie, 2003; Hassanpanah et al., 2018).

An analysis of variance was performed to probe into the split-plot after the confirmation of data normality from the measurement of traits. The comparison of the means of measured traits was conducted via the LSD test, with a 5\% probability level adopted. Statistical computation was performed using SAS software (version 9.1). The software, in combination with the SAS-Griffing method III program, was used to estimate the effects of general and specific combining abilities and genetic components on the hybrids.

The effects of GCA and SCA were also determined following the method proposed by Moghadam and Amiri-Oghan (2010). Standard errors of variance components for the effects of general and specific combining abilities were calculated using the method described by Vasal et al. (1992). Variances in general and specific combinations in potato (Bradshaw, 2006), degree of dominance, and general and specific inheritance (Teklewold and Becker, 2005) were estimated.

\section{Results and Discussion}

From 135 crosses among the Luca, Esprit, Banba, and Agria cultivars, 8550 TPSs were produced from 12 breeding populations. Of these, 3944 seeds were germinated, and 151 hybrids were selected for culturing on the split-plot. The selected hybrids had a mean tuber weight and number per plant of about 948 grams and 6.92 tubers per plant, respectively (data not shown).

The highest tuber yield was that from the hybrids of Esprit $\times$ Luca $\widehat{O}$ and + Luca $\times$ Banba $\widehat{O}$ under normal conditions (100\% available water); in the hybrids of

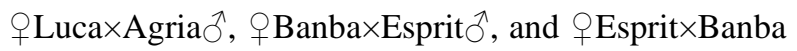
$\widehat{\jmath}$ under mild stress conditions ( $85 \%$ available water); and in the hybrid of + Luca×Agria ${ }^{\top}$ in severe stress conditions $(70 \%$ available water). The hybrid of

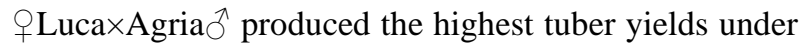
mild and severe stress conditions (data not shown). The analysis of variance showed significant differences among the hybrids in terms of water deficit stress, genotypes, and their interaction as regards tuber yield at a probability of $1 \%$ (Table 2 ). These differences pointed to sufficient genetic diversity among the crosses for tuber yield.

The analysis of variance for tuber yield concerning the effects of GCA, SCA, and reciprocals (REC) at $100 \%$ and $85 \%$ available water and in terms of the effects of GCA and REC at $70 \%$ available water showed a 
significant difference at the probability level of $1 \%$ (Table 3). A significant difference at the probability levels of $5 \%$ and $1 \%$ was found based on the GCA of the Luca, Banba, and Esprit cultivars; the SCA of the $\delta^{\lambda}$ Luca $\times$ Esprit $q$ and $\lambda$ Luca $\times$ Agria + combination; the REC effects of the ${ }^{\lambda}$ Banba $\times$ Luca ${ }_{+},{ }^{\lambda}$ Esprit $\times$ Luca ${ }_{+}$,

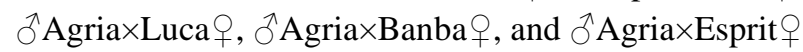
combinations; the interaction between the GCA of the Banba and Esprit cultivars with the three water stress conditions; the interaction between the SCA of the ${ }^{7}$ Luca $\times$ Esprit 9 combination with the three water stress conditions; and the REC effects on the ${ }^{\lambda}$ Banba $\times$ Luca 9 and $\widehat{\jmath}$ Agria $\times$ Esprit $q$ combinations in terms of tuber yield (Table 4).

The highest GCA for positive and significant tuber yield was observed in the Luca cultivar, and negative and significant differences were found between the Banba and Agria cultivars under normal conditions (100\% available water). The cultivars exhibited non-significant differences under mild and severe stress conditions (85\% and $70 \%$ available water, respectively) (Table 5). According to the estimated GCA effects of the cultivars, the highest positive GCA for tuber yield was that of the Luca cultivar under normal conditions. In contrast, the lowest were those of the Agria and Banba cultivars (Table 5).

The highest SCA for tuber yield was found in the direct cross of the ${ }^{\lambda}$ LucaxEsprito compound; a significantly positive SCA was found in the direct cross of the ${ }^{\lambda}$ BanbaxAgria $q$ compound, and a significantly negative SCA was observed in the direct cross under normal and mild conditions. The highest SCA for tuber

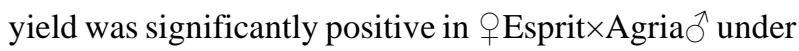
normal conditions and in the $q$ BanbaxEsprit $\widehat{\partial}$, and

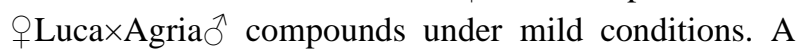
significantly negative SCA was found in the reciprocal crosses of $q$ Banba $\times$ Agria $o ̂$ under normal conditions and $\uparrow$ BanbaxAgria $\bigcirc$ under mild conditions (Table 5).

The direct cross of the QLucaxEsprit 9 compound had the highest tuber yield. Among the studied cultivars, the Luca variety exhibited a GCA that was positive and significant for tuber yield under normal conditions. This finding indicated that Luca could be used in breeding programs as suitable parents. In this regard, the use of cultivars with an SCA that is positive and significant for tuber yield is emphasized. Crossing the Luca cultivar with the Esprit cultivar generated a positive and significant SCA.

In all the three environments, the general heritability of tuber yield ranged from $81.68 \%$ (in $70 \%$ available water) to $94.66 \%$ (in $100 \%$ available water). The specific heritability of tuber yield ranged from $62.39 \%$ (in $85 \%$ available water) to $86.78 \%$ (in $100 \%$ available water). Additive variances were $118.05,46.92$, and 37.49 , and dominance variances were $33.82,8.97$, and 0.68 in $100 \%$, $85 \%$, and $70 \%$ available water, respectively (Table 6).

Table 1. Water supplied using tape irrigation $(100 \%, 85 \%$, and $70 \%)$.

\begin{tabular}{ccccc}
\hline Levels & Irrigation number & $\begin{array}{c}\text { Water consumed amount } \\
\left(\mathrm{m}^{3} \text { per ha }\right)\end{array}$ & $\begin{array}{c}\text { Effective rain amount } \\
\left(\mathrm{m}^{3} \text { per ha }\right)\end{array}$ & $\begin{array}{c}\text { Applied water volume* } \\
\left(\mathrm{m}^{3} \text { per ha }\right)\end{array}$ \\
\hline $100 \%$ & 13 & 7071.24 & 562 & 7633.24 \\
$85 \%$ & 13 & 6010.55 & 562 & 6572.55 \\
$66 \%$ & 13 & 4596.31 & 562 & 5158.31 \\
\hline
\end{tabular}

*Applied water volume: Amount of water consumed + Amount of effective rainfall.

Table 2. Variance analysis of tuber yield in potato hybrids under water deficit conditions.

\begin{tabular}{ccc}
\hline S.O.V & D.F. & M.S. \\
\hline Water deficit (A) & 2 & $1630.71^{* *}$ \\
Error 1 & 6 & 32.45 \\
\hline Genotype (B) & 11 & $247.38^{* *}$ \\
A $\times$ B & 22 & $41.81^{* *}$ \\
Error 2 & 66 & 803.92 \\
\hline C.V.\% & - & 10.059 \\
\hline
\end{tabular}

**Significant difference at $1 \%$ probability level.

Table 3. Analysis variance of GCA and SCA of potato tuber yield in hybrids under $100 \%, 85 \%$, and $70 \%$ available water.

\begin{tabular}{ccccc}
\hline S.O.V. & D.F. & & MS & Tuber Yield in \\
\cline { 3 - 5 } & & Tuber Yield in & Tuber Yield in & $27.84^{* *}$ \\
GCA & 3 & $81.55^{* *}$ & $34.13^{* * *}$ & $1.802 \mathrm{~ns}$ \\
SCA & 4 & $19.04^{* *}$ & $6.623^{* *}$ & $26.86^{* *}$ \\
REC & 6 & $38.41^{* *}$ & $46.93^{* *}$ & 8.559 \\
E & 66 & 8.56 & 8.563 & \\
\hline
\end{tabular}

**Significant difference at $1 \%$ probability level. ns: Non-significant difference. 
Table 4. Variance analysis of general, specific, and reverse combining abilities of tuber yield in potato hybrids.

\begin{tabular}{|c|c|c|}
\hline S.O.V & D.F. & M.S. \\
\hline G1 (Luca) & 1 & $46.6891^{*}$ \\
\hline G2 (Banba) & 1 & $342.544 * *$ \\
\hline G3 (Sprit) & 1 & $409.982 * *$ \\
\hline S13 $(\overbrace{}^{\Uparrow}$ Luca $\times$ Esprit $\bigcirc)$ & 1 & $512.587 * *$ \\
\hline $\mathrm{S} 14(\overbrace{}^{\lambda}$ Luca $\times$ Agria + ) & 1 & $538.685 * *$ \\
\hline R12 ( ${ }^{\top}$ Banba $\times$ Luca + ) & 1 & 0.68056 \\
\hline R13 ( ${ }^{\lambda}$ Esprit $\times$ Luca ${ }^{\prime}$ ) & 1 & $368.471 * *$ \\
\hline R14 $\left(\partial^{\top}\right.$ Agria $\times$ Luca + ) & 1 & $95.8651 * *$ \\
\hline R24 ( $\overbrace{}^{\top}$ Agria $\times$ Banba + ) & 1 & $229.051 * *$ \\
\hline R34 ( $\supset^{\lambda}$ Agria $\times$ Esprit + ) & 1 & $172.113 * *$ \\
\hline $\mathrm{G} 2 \times \operatorname{ENV}($ Banba $)$ & 2 & $56.4289 * *$ \\
\hline $\mathrm{G} 3 \times \mathrm{ENV}($ Esprit $)$ & 2 & $36.7274 *$ \\
\hline S13 $\times$ ENV $(\overbrace{}^{\lambda}$ Luca $\times$ Esprit 9$)$ & 2 & $59.7886 * *$ \\
\hline $\mathrm{R} 12 \times \operatorname{ENV}(\overbrace{}^{\Uparrow} \mathrm{Banba} \times \mathrm{Luca}$ 우 $)$ & 2 & $93.406^{* *}$ \\
\hline R34 $\times$ ENV $\left({ }^{\top}\right.$ Agria $\times$ Esprit 9 ) & 2 & $38.4993 *$ \\
\hline
\end{tabular}

Table 5. Estimation of GCA (on diameter), SCA (upper half), and inverse (lower half) potato tuber yield in normal, mild, and severe stress conditions.

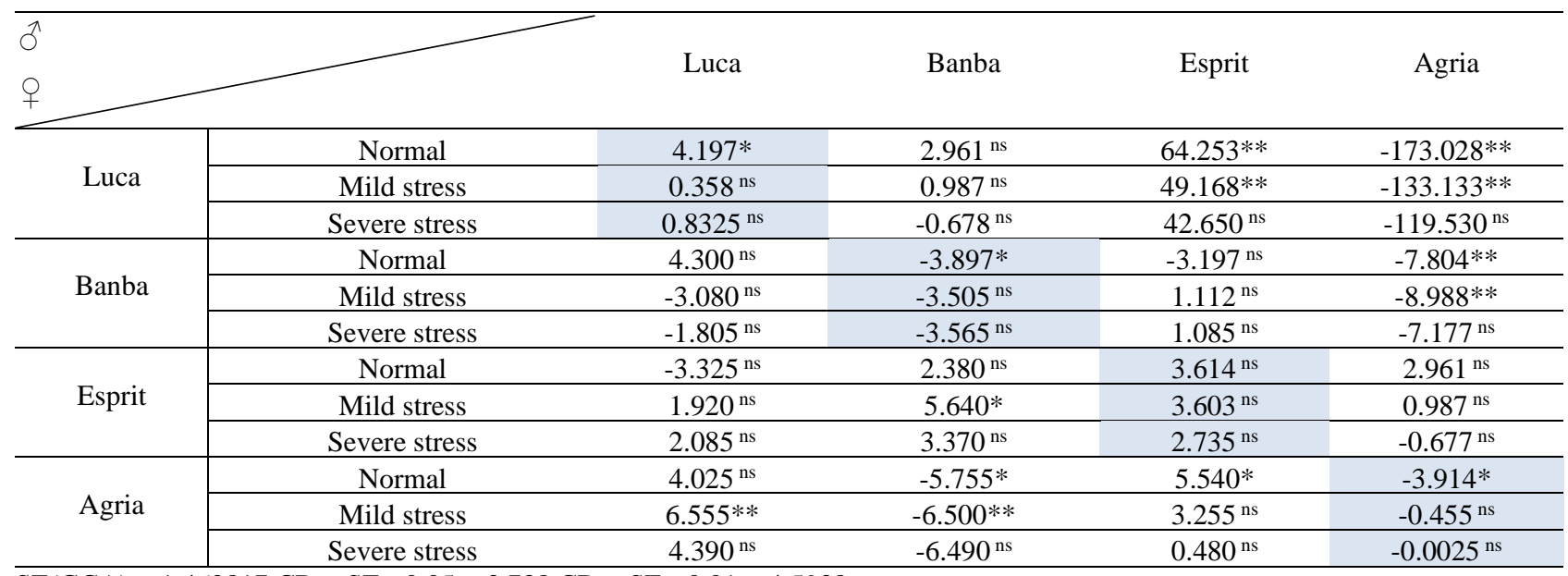

$\mathrm{SE}(\mathrm{GCA})=1.462817 \mathrm{CD}=\mathrm{SE} \times \mathrm{t} 0.05=3.738 \mathrm{CD}=\mathrm{SE} \times \mathrm{t} 0.01=4.5938$.

$\mathrm{SE}(\mathrm{SCA})=1.462817 \mathrm{CD}=\mathrm{SE} \times \mathrm{t} 0.05=3.738 \mathrm{CD}=\mathrm{SE} \times \mathrm{t} 0.01=4.5938$

$\mathrm{SE}(\mathrm{REC})=2.068735 \mathrm{CD}=\mathrm{SE} \times \mathrm{t} 0.05=5.294 \mathrm{CD}=\mathrm{SE} \times \mathrm{t} 0.01=6.4957$.

Table 6. Genetic components of tuber yield in genotypes under normal, mild, and severe stress conditions.

\begin{tabular}{cccc}
\hline Combining ability & In $100 \%$ available water & In $85 \%$ available water & In $70 \%$ available water \\
\hline GCA & 59.026 & 23.46 & 18.74 \\
SCA & 33.80 & 8.97 & -0.68 \\
REC & 110.94 & 136.52 & 76.31 \\
GCA $/$ SCA & 1.75 & 2.616 & -27.76 \\
$\delta^{2} \mathrm{a}=2 \delta^{2} \mathrm{~g}$ & 118.05 & 46.92 & 37.49 \\
$\delta^{2} \mathrm{~d}=\delta^{2} \mathrm{~s}$ & 33.82 & 8.97 & 0.68 \\
$\delta^{2} \mathrm{~g} / \delta^{2} \mathrm{~s}$ & 3.49 & 5.23 & -55.53 \\
Degree of dominance & 0.54 & 0.44 & 0.14 \\
General heritability & 94.66 & 86.72 & 81.68 \\
Specific heritability & 81.33 & 62.39 & 86.78 \\
\hline
\end{tabular}

From 135 crosses among the Luca, Esprit, Banba, and Agria cultivars, 8550 TPSs were derived from 12 breeding populations, of which 3944 seeds were germinated, and 151 hybrids were selected. The chosen hybrids had a mean tuber weight and number per plant of approximately 948 grams and 6.92 tubers per plant, respectively. A significant difference was found among the GCA, SCA, and REC effects in $100 \%$ and $85 \%$ available water and between the GCA and REC effects in $70 \%$ available water.

Some researchers also reported significant GCA and SCA effects for potato, with values indicating exploitable genetic variations (Tai, 1976; Mwanga et al., 2002; Ahmad et al., 2009; Kaushik and Dhaliwal, 2018). Tai 
(1976) found significant GCA and SCA effects on tuber yield in potato cultivars in a partial diallel cross experiment. The effects of general and specific combining abilities are important in controlling traits as well as additive and non-additive effects (Ahmad et al., 2009).

In the current work, the significance of GCA effects pointed to the role of additive effects in the regulation of tuber yield. According to the estimated GCA effects on the cultivars, the highest positive GCA for tuber yield was achieved with the Luca cultivar under normal conditions. In contrast, the lowest was registered in the Agria and Banba cultivars. The negative GCA for tuber yield was in the Banba and Agria cultivars in normal conditions, indicating minimal trait transferability, which thereby reduced the extent of expression in the offspring.

Based on the results, the Luca cultivar was the best combiner for tuber yield under normal conditions. The cultivars exhibited non-significant differences under mild and severe stress conditions. The direct cross of the qLuca $\times$ Esprit $q$ compound had the highest tuber yield. Crossing the Luca and Esprit cultivars generated a positive and significant SCA.

The study also found one parent with a positive and significant GCA and two parents with a negative and significant GCA. SCA expresses the non-additive contribution of genetic variance (Hosana et al., 2015).

Finally, the excellent combiner effects on tuber yield in the Luca variety drove the interaction between additivexadditive and additivexdominance. Therefore, this parent may be used to improve different crosscombinations. The Agria and Banba cultivars do not count as candidates for tuber yield in breeding programs because they produced a negative GCA for such yield. The estimation of general and specific combining abilities helps breeders decide on which breeding programs and genotype selection strategies to adopt (de la Vega and Chapman, 2006).

The suitability of the Luca cultivar for use as a parent in breeding programs emphasized the adoption of cultivars with a significant and positive SCA for tuber yield. As mentioned earlier, crossing the Luca cultivar with the Esprit cultivar produced a positive and significant SCA.

As reported by Kaushik and Dhaliwal (2018), hybrid combinations of $\mathrm{H} 23, \mathrm{H} 42$, and $\mathrm{H} 49$ could be considered efficient for the selection of multiple traits, including yield. Gautam et al. (2018) concluded that parents of UHFT-9, UHFT-10, and UHFT-55 had good GCA for quality traits. The hybrids UHFT- $9 \times$ Solan Lalima, UHFT-10×Solan Lalima, UHFT-22×Solan Lalima, and UHFT-55×EC-2798 showed significant SCA effects, suggesting the presence and exploitation of heterosis for the production of various quality traits in crosses.
Ngailo et al. (2019) reported that parental genotypes Simama and Gairo exerted positive and significant GCA effects on the number of storage roots per plant. The parents 03-03, Ukerewe, and Simama had significant and positive GCA effects on storage root yield and dry matter content, respectively. Additive variances were 118.05, 46.92, and 37.49, and dominance variances were 33.82, 8.97 , and 0.68 in $100 \%, 85 \%$, and $70 \%$ available water, respectively. Collins (1977) found an additive variance of about $87 \%$ for total genetic variance but a dominance variance of only $13 \%$. The broad-sense and narrow-sense heritabilities estimated for individuals and full-sib families were consistently greater than $70 \%$. The narrowsense heritability of individuals for which parentoffspring regression was used was $50 \%$.

Aliu et al. (2008) derived a GCA-to-SCA ratio of 0.25 , while Mwanga et al. (2002) obtained narrow-sense heritabilities of $31 \%$ to $41 \%$ and broad-sense heritabilities of $73 \%$ to $98 \%$. In Kaushik and Dhaliwal's (2018) research, the broad-sense heritability values were larger than the narrow-sense heritability values, showing that selection efficiently improves these traits.

Sharavati et al. (2018) indicated that the PVC was higher than the GVC for all traits and discovered the existence of a broad genetic base, which would be amenable to further selection. In the present study, the general heritability of tuber yield was $81.68 \%$ (in $70 \%$ available water) to $94.66 \%$ (in $100 \%$ available water), and the specific heritability of tuber yield ranged from $62.39 \%$ (in $85 \%$ available water) to $86.78 \%$ (in $100 \%$ available water). Mwanga et al. (2002) generated a GCA/SCA ratio of 0.51 to 0.87 ; hence, GCA effects were more important than SCA effects. A ratio close to 1 denotes the essentiality of additive effects in determining a trait. If the degree of dominance exceeds 1 , then superdominance or false dominance is imposed on the genes controlling this trait (Sharifi et al., 2010).

\section{Conclusions}

- The hybrid of $Q_{\text {Luca }} \times$ Agria $\widehat{\jmath}$ under mild and severe stress conditions had the highest tuber yield.

- The direct cross of $q$ LucaxEsprit $\bigcirc$ compound had the highest tuber yield.

- Crossing Luca cultivar with Esprit cultivar had specific combine ability positive and significant.

- The general heritability of the tuber yield was from 81.68 (in $65 \%$ available water) to $94.66 \%$ (in $100 \%$ available water) and specific heritability from 62.39 (in $85 \%$ available water) to $86.78 \%$ (in $100 \%$ available water).

- The additive variance was $118.05,46.92$, and 37.49 , and dominance variance about $33.82,8.97$, and 0.68 in 100,85 , and $65 \%$ available water, respectively. 


\section{Acknowledgments}

Special thanks go to the management and partners of Ardabil Agricultural and Natural Resources Research and Education Center in Ardabil, Iran for granting us the use of facilities and extending scientific support.

\section{Bibliographic References}

Ahmad, S., Quamruzzaman, A.K.M., Nazim Uddin, M., 2009. Combining ability estimates of tomato (Solanum Lycopersicum L.) in late summer. SAARC, Journal of Agriculture, 7(1), 4356.

Aliu, S., Fetahu, S.H., Salillari, A., 2008. Estimation of heterosis and combining ability in maize (Zea mays L.) for ear weight (ew) using the diallel crossing method. Latvian Journal of Agronomy, 11, 7-12.

Baafi, E., Gracen, V.E., Aduening, J.M., Blay, E.T., Ofori, K., Carey, E.E., 2017. Genetic control of dry matter, starch and sugar content in sweet potato. Acta Agriculturae Scandinavica, Section B: Soil \& Plant Science, 67(2), 110-118.

Bradshaw, J.E., 2006. Genetics of agrihorticultural traits, in: Gopal, J., Khurana S.M.P., (Eds.). Handbook of potato production, improvement and postharvest management. The Haworth Press, Binghamton, p. 41-75.

Bradshaw, J.E., Todd, D., Wilson, R.N., 2000. Use of tuber progeny tests for genetical studies as part of a potato (Solanum tuberosum subsp. tuberosum) breeding programme. Theoretical and Applied Genetics, 100(5), 772-781.

Çelik, M., Yildirim, M., Yildirim, Z., 2015. Potato proteins. Niğde Üniversitesi Mühendislik Bilimleri Dergisi, 4(2), 68-77.

Collins, W.W., 1977. Diallel analysis of sweet potatoes for resistance to Fusarium wilt. Journal of the American Society for Horticultural Science, 102(2), 109-111.

De La Vega, A.J., Chapman, S.C., 2006. Multivariate analyses to display interactions between environment and general or specific combining ability in hybrid crops. Crop Science, 46(2), 957-967.

El-Badawy, M.E.M., 2013. Heterosis and combinig ability on Maize using Diallel crosses among seven new inbred line. Asian Journal of Crop Science, 5(1), 1-13.

Gautam, N., Kumar, M., Kumar, D., Kumar, S., Vikram, A., Dogra, R.K., Sharma, S., 2018. Combining ability and gene action studies for important quality traits in tomato (Solanum Lycopersicum L.). International Journal of Chemical Studies, 6(2), 1992-1996.

Griffing, B., 1956. Concept of general and specific combining ability in relation to Diallel crossing systems. Australian Journal of Biological Sciences, 9(4), 463-493.

Harriman, J.C., Nwammadu, C.A., 2016. Utilization of diallel analyses for heritability, GCA and SCA studies in crop improvement. American Advances Journal of Biological Sciences, 2(5), 159-167.

Hassanpanah, D., Kazemi, M., Mousapour Gorji, A., Jalali, A.H., 2018. A comprehensive guide of potato cultivation. Nashre Amozesh Keshavarzi, 324 p.
Hosana, G.C., Alamerew, S., Tadesse, B., 2015. Test cross performance and combining ability of maize (Zea Mays L.) inbred lines at Bako, Western Ethiopia. Global Journal of Science Frontier Research: D Agriculture. And Veterinary, 15(4), 1-24.

Jansky, S.H., Spooner, D.M., 2018. The evolution of potato breeding. Plant Breeding Reviews, 41, 169-214.

Kaushik, P., Dhaliwal, M.S., 2018. Diallel analysis for morphological and biochemical traits in tomato cultivated under the influence of tomato leaf curl virus. Agronomy, 8(153), 1-15.

Moghadam, M., Amiri-Oghan, H., 2010. Biometric methods in quantitative genetic analysis. Publisher Parivar, 415 p.

Mwanga, R.O.M, Yencho, G.C., Moyer, J.W., 2002. Diallel analysis of sweet potatoes for resistance to sweet potato virus disease. Euphytica, 128(2), 237-248.

Neele, A.E.F., Nab, H.J., Louwes, K.M., 1991. Identification of superior parents in a potato breeding programme. Theoretical and Applied Genetics, 82(3), 264-272.

Ngailo, S., Shimelis, H., Sibiya, J., Mtunda, K., Mashilo, J., 2019. Genotype-by-environment interaction of newlydeveloped sweet potato genotypes for storage root yield, yieldrelated traits and resistance to sweet potato virus disease. Heliyon, 5(3), 1-23.

Ortiz, R., Golmirzaie, A.M., 2003. Genetic parameters for agronomic characteristics. II. Intermediate and advanced stages in a true potato seed breeding population. Hereditas, 139(3), 217-222.

Panel, P.R., 2017. Teagasc potato breeding programme peer review panel. Agriculture and Food Development Authority Teagasc, $26 \mathrm{p}$.

Rasoulzadeh, A., Raof, M., 2013. Principles and methods of irrigation. Amidi, 283 p.

Sharavati, M.B., Srinivasa, V., Anusha, R.B., Shubha, A.S., 2018. Genetic Variability Studies in Sweet Potato (Ipomoea batatas (L.) Lam) Genotypes under Hill Zone of Karnataka, India. International Journal of Current Microbiology and Applied Sciences, 7(9), 850-858.

Sharifi, P., Dehghani, H., Momeni, A., Moghadam, M., 2010. Diallel analysis for heterosis study and estimation of genetic parameters for some morphological traits in rice. Seed and Plant Improvement Journal, 26(1), 77-104.

Swetha, S., Nidagundi, J.M., Diwan, J.R., Lokesha, R., Hosmani, A.C., Hadimani, A., 2018. Combining ability studies in cotton (Gossypium barbadense L.). Journal of Pharmacognosy and Phytochemistry, 7(1), 638-642.

Tai, G.C.C., 1976. Estimation of general and specific combining abilities in potato. Canadian Journal of Genetics and Cytology, 18(3), 463-470.

Teklewold, A., Becker, H.C., 2005. Heterosis and combining ability in a diallel cross of Ethiopian mustard inbred lines. Crop Science, 45(6), 2629-2635.

Vasal, S.K., Srinivasan, G., Pandey, S., Córdova, H.S., Han, G.C., Gonzalez, F., 1992. Heterotic pattern of ninety-two white tropical CIMMYT maize lines. Maydica, 37(2), 259-270. 